\title{
The Requirement of Written Opinions
}

It is provided by the Constitution of the State of California: ${ }^{1}$

"In the determination of causes [by the Supreme Court], all decisions of the court in bank or in department, shall be given in writing, and the grounds of the decision shall be stated."

Nothing is said as to where and how these decisions are to be reported or the type in which they are to be printed. There is no specific obligation to prepare syllabi or to discuss every point raised by the contending parties. That is to say, our constitutional provision does not contain all the elements which have at least twice been called inconvenient and objectionable by the highest courts of other states. ${ }^{2}$ But the constitutional mandate is there and the question arises whether it serves any good purpose.

That the results are inconvenient, to say the least, will be conceded. For the litigants, the result is an inevitable and increasing delay in the final disposition of causes. For the lawyer, the result is that each year six substantial volumes must be acquired and their contents completely and thoroughly examined. And this must be done in addition to the vast accumulation of legal material from other sources which to a greater or less degree he must sonehow master. My Lord Coke, writing in an age when opinions were brief, oral and optional - if they can be said to have existed at all - and when statutes were relatively few, felt himself overwhelmed by the increase of the latter alone and cited the distich of "a wise man" to explain the unfortunate condition. We might repeat with him:

Quaeritur ut crescunt tot magna volumina legis?

but in Cahfornia we should have to add:

Causa in promptu est. Hoc statuere patres. ${ }^{3}$

A large part of our burdens has been imposed on us by a group of men who fifty years ago imbedded in a long paragraph, a sentence which in all likelihood most of them never noted, since the attention of the Constitutional Convention of 1879 was directed to other provisions.

California is not alone in this respect. Apparently similar provisions are found in the statutes or constitutions of Alabama, Arizona, Indiana,

1 Cal. Const., art. VI, $\$ 2$.

2 Baker v. Kerr (1862) 13 Ta. 384; Ex parte Griffiths (1889) 118 Ind. 83, 20 N. E. 513, 3 I. R. A. 398,10 Am. St. Rep. 107.

3 Coke's second line runs: "Causa in promptu est. Crescit in urbe dolus." "The reason is at hand. Fraud grows apace in our city." The amendment I have ventured to make is therefore of the slightest and it is Coke or the perhaps mythical "wise man" who must bear the responsibility for the hiatus after promptu. The amended distich we may paraphrase as follows: "The law piles up in volumes thick and tall. The reason's plain. 'Tis constitutional." 
Maryland, Missouri, Ohio, Oregon, and South Carolina. ${ }^{4}$ It is to be noted that New York and Massachusetts are not in this list, nor is England, the oldest of the common-law jurisdictions. How did this provision get into the constitution of the state and why?

We must go back to that extraordinary personage, Mr. Justice Stephen Field, who in 1859 decided the case of Houston $v$. Williams, ${ }^{5}$ a decision widely cited and in a measure the leading case on the subject in the United States. Field declared that the statute of May 15, 1854, which provided substantially what the Califorma Constitution now provides was "a palpable encroachment upon the independence of this [the judicial] department" and was unconstitutional. It is interesting to note that in this he had the concurrence of Chief Justice Terry, a gentleman not prone to concur.

That Houston v. Williams excited a great deal of opposition is not likely. It does not seem to have gotten into general popular notice. It may have irked some lawyers and doubtless did irk the particular lawyer whose contention was thereby set aside without detailed reasons. But the Constitution of 1862 did not mention the point at all and the reports between 1859 and 1879 contain a number of brief and summary opinions, sometimes reversing and sonietimes affirming. A certain number of cases were decided without opinion and several of these were reversals.

Evidently there was a gathering objection to the practice. It is hard to believe that it was a popular objection. But there was always a popular and persistent rancor against the judiciary as an institution and lawyers who had any reason for attacking it would be fairly sure of obtaining popular support. Therefore, when the Constitutional Convention met in 1878, we find Mr. George W. Schell proposing the following amendment:

"When a judgment or decree is reversed or affirmed by the Supreme Court, every point fairly arising upon the record of the case shall be considered and decided; and the reasons thereof shall be concisely stated in writing and preserved with the record of the case; and it shall be the duty of the Court to prepare a syllabus of the points adjudicated in each case concurred in by three of the Judges thereof, which shall be prefixed to the published report of the case." 6

The proposal follows very closely existing provisions in other states, even to the word "concisely" and the duty to prepare a syllabus. It

4 AIA. Code (1907) \$4628; Arzz. Rev. Stat. (1887) 948; Ind. Const., art. 7, §5; Mo. Const., art. 4, §15; Mo. Const., art. 6, \$23; Omro Gen. Code §12248; Ore. Const., art. $7, \S 7 ;$ S. C. Const., art. $8, \S 7$.

5 (1859) 13 Cal. 24, 73 Am. Dec. 565.

61 Debates and Proceedings of the Constitumional Conventron of the State of Carifordia (1880) 165. 
was referred to the Judiciary Committee of the Convention and never reported out.

But on January 8, 1879 the entire sixth article of the present Constitution was reported out and debated. ${ }^{\top}$ It was ultimately accepted with very little, if any, change and the sentence referring to judicial opinions was adopted verbatim.

The article was vigorously debated and the debate concerned itself with the method of departmentalizing the work of the court and the increase in the number of justices fron five to seven. It may be said that the question of written opinions was not debated at all.

However, Mr. Saniuel M. Wilson used the absolute necessity of giving written opinions as one of the chief reasons for demanding both an increase in the number of judges and the creation of departments.

"The business of the Supreme Court of the State of California is, I think, larger than that of any Supreme Court in the American Union; larger than the Supreme Court of any other State. The report made to the Convention by the Clerk of the Supreme Court shows that during the four years past there have been brought and filed in that Court some two thousand and sixty-seven cases, making an immense ealendar for that period of time. The Supreme Court has decided, during that time, some two thousand two hundred and forty-two eases. Of course, it decided more cases than were filed during that period, the excess being caused by the old eases on file previous to their going into office. We have thus an average of five hundred and sixty-six and one half cases a year decided by the present Supreme Court during the last four years, which is an almost incredible amount of labor. I do not think it has been surpassed, or ean be surpassed, anywhere. But in order to enable the Court to accomplish that work, it had to decide five hundred and fifty-nine cases without giving any opinion in writing. If it is proper and right that a Court of last resort should deliver opinions in writing, giving the reasons for its decisions, we have it demonstrated that the Court, as heretofore constituted and organized, could not possibly perform its duties, for it could not have rendered that number of decisions and bave delivered written opmions upon them. The importance of requiring the Court to give written opinions cannot be overrated. They not only become the settled law of the State, and are precedents for subsequent cases, but in many causes where the litigation is not ended by the decision of the Supreme Court, and new trials are consequent upon a reversal, the decision of the Supreme Court should be given in writing, and reasons assigned, for they are instructions to the Court below, and are the controlling rule in the subsequent litigation.

"Any gentleman who has practiced in the Supreme Court knows that cases have been sent back for new trial, without written opinions, and the Courts below have been unable to ascertain the full views of the appellate Court upon the case. Four or five points may be presented. The

72 Debates and Proceedings of the Constitutional Convention of the State of California (1880) 949 et. seq. 
Supreme Court may reverse the case, and send it back for a new trial, upon some one of these points, but upon which point the lawyers are unable to say - whether on five points or on one. The result is that the new trial in the Court below takes place without any light from above, and the case may be appealed a second time, and again reversed upon some one of the same points, and so, ad infinitum; whereas, if a written opinion were rendered, it might end the case without a second appeal. That practice shows the inefficiency of any system wbere written opinions are not required, and everywhere throughout the United States the Courts are required to deliver written opinions, stating the grounds of the decision, as we have provided in this section. Undoubtedly it will insure a careful examination of the cases, and result in well considered opinions, because they must come before the jurists of the country and be subjected to the severest criticism. I think every lawyer will agree with me, that in every case there should be an opinion in writing. It tends to purity and lonesty in the administration of justice. But, as the Supreme Court is now constituted, it is unable to dispose of the cases annually coming before it and render written decisions, for no five men on the face of the earth can dehiberately determine five hundred and sixty cases a year, and render written opimions on them, commensurate with the importance and character of the cases brought in this Court. The object, then, of the committee, was to increase the power of the Supreme Court, not simply in point of numbers, but to increase its effective working power; and the question was simply this: How shall we enable the Court to perform its duties? how shall we increase its effective working power? Now, to increase the number of Judges does not, in itself, increase, to any great extent, the working power of the Court, because, instead of five Judges to canvass a case, and read the transcript and briefs, we would have seven men to do the same work, which would rather retard than dispatch business. We have, therefore, after mature consideration and much thought over the matter, concluded to adopt the plan of increasing the number of Judges from five to seven and authorizing the Court to sit in two departments at the State Capitol. ...

"There are on the docket of the Supreme Court of the United States about one thousand cases, and the Court cannot dispose of more than about two hundred and sixty cases a year. The Supreme Court of the United States, composed of nine Judges - effective, active, working men - are unable to dispose of inore than two hundred and sixty cases a year, while the Supreme Court of this State has disposed of five hundred and sixty cases a year. But they were only enabled to do that, as I said before, by omitting written opinions; whereas the Supreme Court of the United States universally delivers written opinions, giving the reasons in full." 8

No other speaker referred to the question, and it is doubtful whether Mr. Wilson laid much stress on this portion of his argument. We may say, therefore, that the sentence got into the Constitution

8 It need hardly be pointed out that the Supreme Court of the United States does not "universally" deliver written opinions giving reasons in full, but on the contrary decides many appeals with a inere memorandum of affirmance. 
of California because Mr. Wilson was sure every lawyer wanted written opinions and was by nature entitled to have them and because written opinions could be made a forcible argument for something that really interested the convention, that is, the number of justices, and the place and methods of their deliberations.

It will be noted further that what roused Mr. Wilson to demand written opinions was the practice of reversing a decision of a lower court without an opinion, an act which is open not only to the objections urged by him, but to many other objections as well, not the least of which is that it is a discourtesy to the court below.

Most cases, lowever, are not reversed but affirmed, and they are at the present affirmed after a judge of the Superior Court and generally two or three judges of the District Court of Appeal have already fully considered and determined the matter and usually after a fairly extensive opinion in writing has already been filed and published. Evidently Mr. Wilson's objections at once fall in sucl a case, and the objection of discourtesy falls with it. Nor is an affirmation without opinion a discourtesy to appellant's counsel. It is merely an assertion that he has failed to convince the highest court that serious or grave errors liave been committed by the court below. An appeal is not an academic discussion of moot points, and counsel is not entitled as a matter of fraternal amenity to an opinion from his judicial brethren on all topics that may interest him.

We have, therefore, still to seek a reason why every decision in every case by the Supreme Court must by fundarnental law be accompanied by a written statement of why the decision was rendered.

The experience and practice of other jurisdictions may be helpful. Every now and then, courts use terms as broad as those of $\mathrm{Mr}$. Wilson, without lraving Mr. Wilson's reasons. So in Ayres v. United States, ${ }^{9}$ the Court of Claims discovered that the requirement of written opinions was a "cardinal principle of Anglo-Saxon jurisprudence," in which dictum the word "cardinal," the word "principle" and the word "Anglo-Saxon" are somewhat excessive. In general, however, courts have found the provisions of this sort burdensome and unnecessary. In Vaughn v. Harp ${ }^{10}$ and in State v. District Court, ${ }^{11}$ the Arkansas and Montana courts followed Houston v. Williams ${ }^{12}$ and declared a statute requiring written opinions to be unconstitutional. In Iowa and Indiana the requirement was declared inconvenient and objectionable. ${ }^{13}$ An old

\footnotetext{
9 (1908) 44 Ct. Cl. 48.

10 (1887) 49 Ark. 160, 4 S. W. 751.

11 (1909) 40 Mont. 206, 105 Pac. 721.

12 (1859) 13 Cal. 24, 73 Am. Dec. 565.

13 See supra note 2.
} 
Pennsylvamia case $^{14}$ denied that there was any obligation, moral or legal, upon courts to prepare opinions. And in Missouri, Florida, Maryland, West Virginia, Kansas, Nebraska, as well as Iowa and even Indiana, provisions of this sort whether in statute or constitution have been held to be directory and not mandatory. ${ }^{15}$ In Ohio and Texas only has the requirement been accepted and enforced without judicial objection. ${ }^{10}$

As far as such jurisdictions as the United States Courts, the courts of Massachusetts and those of New York are concerned, we have the familiar spectacle that a great many cases appear in summary form in memoranda. The United States Supreme Court adds to these cases a great number in which certiorari is denied, usually without opinion, and such a denial, while not in terms an affirmance of the court below, has all the effect of an affirmance for that particular question.

It may be worth while to go into the New York practice in detail. The judicial organization of the State of New York takes the form of a Supreme Court of original, general and unlimited jurisdiction, with a limited appellate jurisdiction of cases arising in inferior courts. In each of the four departments of this supreme court there is an Appellate Division, consisting of seven justices in the first department. These seven justices in 1926 heard and decided 1462 appeals and 1427 motions but filed only 338 written opinions. In 1927, they heard 1514 appeals and 1328 motions, but wrote only 376 opinions. In 1928, they disposed of 1543 cases and 1174 motions and rendered 381 written opimons. When we remember that in California the twenty-five judges of our Supreme Court and District Courts of Appeal decided only 1514 appeals, it will be apparent that the seven judges of the New York Appellate Division were able to accomplish more than all the judges of our entire appellate structure.

The Appellate Division in by far the majority of cases is the court of last instance in New York. It is only when the court is divided that there is an appeal as a matter of right to the Court of Appeals. In matters of sufficient importance the Appellate Division or the Court of Appeals may permit an appeal even when the Appellate Division is unanimous.

14 Respublica v. Doan (1784) 1 U. S. (Dall.) 86.

15 City of Miani Beach v. Poindexter (1928) 96 Fla. 811, 119 So. 136; Farwell v. Laird (1897) 58 Kan. 817, 51 Pac. 284; McCall's Ferry Power Co. v. Price (1908) $108 \mathrm{Md}$. 96, 69 Atl. 832; Turner v. Anderson (1911) $236 \mathrm{Mo}$. 523, 139 S. W. 180; Stevens v. State (1898) 56 Neb. 556, 76 N. W. 1055; Horner v. Amicks (1908) 64 W. Va. 172, 61 S. E. 40.

16 Mestetzko v. Elf Motor Co. (1929) 119 Ohio St. 575, 165 N. E. 93; Hartford Fire Insurance Co. v. Galveston, Harrisburg \& San Antonio Ry. (1922) 239 S. W. 919 (Tex.). 
This court, the court of highest instance, is thus required only with matters which prima facie justify a careful examination, whether because they are specifically so considered by the court itself or because a divided court below, itself demonstrates that the matter needs authoritative settlement. In the year 1928, the Court of Appeals heard 609 appeals and 550 motions, of which 355 were applications for leave to appeal; and out of this considerable number they rendered only 280 written opinions. The result is that a case noticed for appeal in this court will be finally determined within two months, or at the most, three. ${ }^{17}$

The first and most important advantage of this system is the obvious one that cases can be disposed of in about eight weeks after the appeal is taken, both in the Appellate Division and in the Court of Appeals. This ought to be conclusive and when we add to it the further fact that the time and energy of the court are not consumed in the reëxamination of matters which have been settlẹd, or in the formal rejection of irrelevant and inconsequential points, it is hard to see what can be urged against a system which is recommended both by reason and experience.

What is the result of the constitutional requirement in California? It is quite true that the Constitution of California does not say how detailed or how summary the written opinion shall be. It does not insist that every point raised in the brief shall be specially considered and determined. But the Cahfornia Supreme Court has chosen almost from the beginning of the 1879 Constitution to interpret the provision liberally, that is to say, it has accepted the interpretation which the bar of the time seems to have put upon the words and has proceeded as though the sentence in article VI, section 2, read as Mr. Schell proposed it should read. Evidently a practice of fifty years cannot lightly be set aside, and should not be. While neither the principle of stare decisis nor any form of estoppel could be invoked, if the Supreme Court were to find that the words of the Constitution are directive only, or that a paragraph with a single case citation is a written opinion, it is plain that such a result would be offensive to the sense of propriety of the bar and bench alike and would arouse a justified resentment that might impair the efficiency of the whole judicial systen. We must, I think, take it that under present conditions, the Supreme Court is under a real duty to pass on all the points which the reckless ingenuity of appellants, undismayed by the high cost of printing, can raise and argue. This apparently necessary interpretation creates a serious situa-

17 See Judge H. A. Hollzer, San Francisco Recorder, June 17, 1930, and The Los Angeles News, June 18, 1930. 
tion-how serious a few figures will indicate. In 1879, Mr. Wilson stated that the five judges disposed of five hundred and sixty cases in one year, a feat which they were able to perform, he asserts, only because written opinions were not required. It is obvious if written opinions had been required, each Justice would have had to prepare two a week. Mr. Wilson apparently thought that seven judges could do it very well, although in that case each judge would have had to write three opinions in two weeks, which is only slightly less burdensome.

Under present conditions, legal business has increased by leaps and bounds. The result has been that described in the State Bar Journal. ${ }^{18}$ The back calendar has reached the portentous total for all the appellate courts of California of 2166 cases, of which 194 were added in 1929 despite an increase in the number of appellate judges and the undeniable improvement in administration of justice created by the Judicial Council. In our present situation a cause will be heard in two years after it has been noticed for appeal and if the recent increase maintains itself, the period will be indefinitely extended.

The law's delay is the ancient burden of the Hymn of Hate which the laity has been chanting against the bar for many centuries. That it is generally caused by the litigants themselves, lawyers know but laymen will not believe. But it certainly does not tend to remove the cause of friction if there is a count in the indictment which definitely and unmistakably must be charged against the legal system itself.

If the section in the Constitution were omitted or modified, California courts could obviously function as those of New York do. It is not likely that more matters involving highly important questions will arise here than arise in New York. Nor is it likely that fewer will arise. Under these circumstances, the experience of a jurisdiction so varied in its problems and so energetic as that of New York certainly permits a reasonable inference that the practice found so effective there will be equally effective here.

If we go back to the conditions before the Constitution of 1879 , it will be seen that, if we may rely on Mr. Wilson's figures, the court was in the habit of writing opinions in about 80 per cent of the cases which it decided. Evidently it is not a question of any fixed proportion; whether an opinion should or should not be rendered in writing will obviously depend on the nature of the decision. And on that point some sensible and pertinent remarks have been made by judges. The following statement of an Iowa court in 1862 is worth examining:

"We are fully aware of the demands of the statute. These are, that the opinions of the court on all questions reviewed on appeal, shall be

184 State Bar JournaI (1929) 253-255. 
reduced to writing, and filed with the clerl: (\$2636), that the court must decide on each error assigned ( $\$ 3546)$, and that no case is decided until the opinion in writing is filed with the clerk $(\$ 3550)$. And we are fully as conscious of the difficulty if not impossibility, of literally complying with all these requirements, consistently with the due and speedy administration of justice, the proper and careful determination of all the causes submitted in this court. And, therefore, in view of the great press of business, in our anxiety to pass upon and adjudicate the causes submitted with as little delay as possible, we have felt at hberty, and indeed that it was our duty, to announce that a case was affirmed, without filing a written opinion, when it was unimportant, involved no new question, and when an opinion would be but repetition and tend to unnecessarily encumber our published reports. And while it is doubtless more satisfactory to counsel, to know, in each case, the grounds upon which a decision is based, it would hardly seem just or reasonable, nor to comport with the theory of our judicial system, that this wish should be gratified, if, as a consequence, we are compelled to hastily consider and determine the heavier and more important questions submitted. Very many cases are brought before us, involving no semblance of error, where, nevertheless, the errors assigned are numerous and oft-repeated (and as often decided previously), where to undertake to pass upon each in a written opimion would require as much time as to determine questions before undecided, of the greatest magnitude. And yet, by the literal reading of the law, this is our duty - a duty, however, which we have never supposed was demanded of us by the pohicy of the state, by the interests of parties litigant, or by the candid and enlightened judgment of the bar.

"And the correctness of this view, and of this professional judgment, finds full support when we remember that we are asked to examine and determine about five hundred cases annually, that, under our new system of practice, questions are constantly arising, requiring early settlement, in which written opinions are absolutely necessary, and that our published reports are accumulating, as in other states, almost, if not quite, beyond the public and professional demand." 10

To this we may add the statement in Stevens $v$. State:

"We have patiently and carefully studied and examined this record, and not one of the contentions made by the plaintiff in error can be sustained. The record presents not one proposition of law which is novel and which has not been time and again decided by this court; and it would subserve no useful purpose whatsoever to write an opinion specifically stating the contentions of the plaintiff in error and our reasons for overruling them. The judgment of the district court is right and is affirmed." 20

The statutes occasionally express a rule that could be followed without difficulty or complaint. So the old Civil Practice Act of Arkansas in 1886 provided that the "court must deliver written opinions in all cases involving a principle of law not previously settled by the court

19 Baker v. Kerr (1862) 13 Ia. at 386.

2056 Neb. 556, 557, 76 N. W. $1055,1056$. 
and reported." ${ }^{21}$ Even this statement was declared by the court to be unconstitutional, on the authority of the California case of Houston v. Williams, ${ }^{22}$ already mentioned. ${ }^{23}$

But the most reasonable rule is that suggested in Letzkus v. Butler, ${ }^{24}$ by which under the legislative provision, the Supreme Court of Pennsylvania could reduce their opinions to writing only in cases of reversal and in such cases of affirmance as should be deemed by a majority of the court to be sufficiently important.

If that rule were in force in California, it would have the salutary result of reducing the necessary labor of court and attorney to a compass which could readily and effectively be managed. It need not be assumed that the court would use the license here given to shirk its task when opinions would be desirable. That has not been our experience in appellate courts. And in the case of the Supreme Court of California, which under a constitutional requirement which has elsewhere been restrictively interpreted, has chosen to follow it in a way distinctly burdensome to itself, it is not to be supposed that they will disregard the purpose and function of written opinions out of a mere desire to avoid labor.

We may note one additional fact. As has been stated, the Califormia Supreme Court before 1879 wrote opinions in about 80 per cent of the cases. In 1929, the Supreme Court heard 351 appeals and decided them with written opinions. The obligation so to do, increases the court's back-calendar appreciably and that increase would still be appreciable if the number of cases ran to 280,80 per cent of the total. But there is a great deal of difference between 1879 and 1930. In 1879,- California's industrial and commercial development had ouly fairly commenced. A great many new situations involving new conflicts and requiring new adjustments were arising and in many of the cases the novelty of the points in this jurisdiction would make written opinions imperative.

But in the fifty years that have since elapsed, the number of these wholly new situations have inevitably decreased. It is quite true that every plaintiff in error is quite sure that no such set of facts as his client's have ever cried to Heaven for a reversal, but as a rule he is hard enough put to it to find a differentiation between his case and other decided cases. In New York we may remember in 1928 an appellate court of five judges wrote 381 opinions in deciding 1543 appeals.

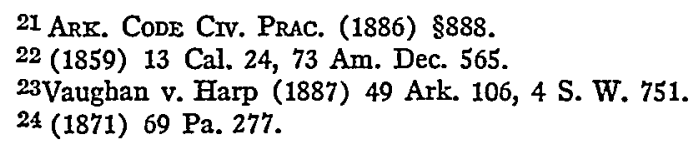


We may take that as our model and we assume conservatively that here as there opinions - full opinions - in one-quarter of the appeals will come nearer to satisfying the demands of common sense and justice. ${ }^{25}$

To cut down the law's delay fron two years and more to a few months, certainly is an earnest of a determined desire to reform what is in the public mind the great and permanent vice of the law: i.e., its procedure. Surely nothing will make clearer that the unhealthy severance between organized justice and the sense of justice in normal men, is a deep concern of lawyers and that as far as the remedy lies in their power, they are eager to apply it.

Max Radin.

SCHOOL OF JURISPRUDENCE,

UNIVERSITY OF CALIFORNIA.

25 The statistics of present judicial practice $I$ owe to the kindness of $\mathrm{Mr}$. Raymond E. Peters, Chief Legal Secretary to the Supreme Court of California. 